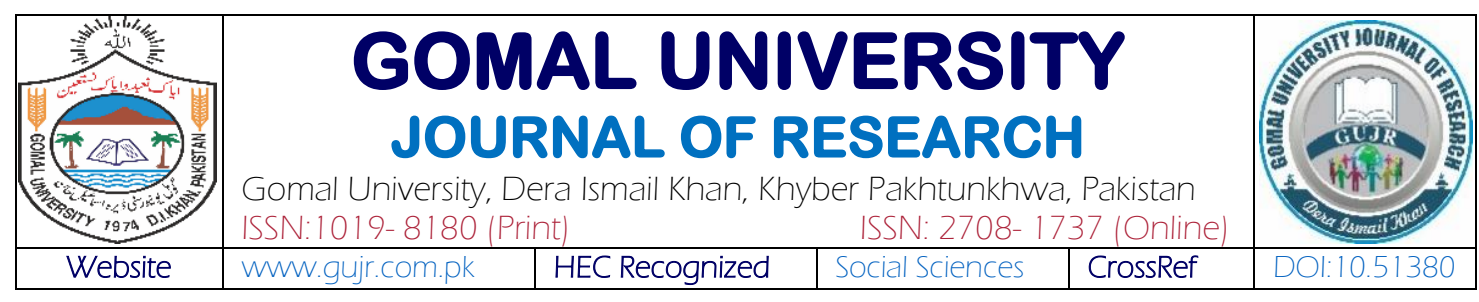

\title{
THE LIGHT TRIAD TRAITS, PSYCHOLOGICAL EMPOWERMENT, CREATIVE SELF-EFFICACY, SELF-RESILIENCE AND INNOVATIVE PERFORMANCE IN ICT OF PAKISTAN
}

Inam Ullah Khan', Umar Safdar² \& Zohair Durrani ${ }^{3}$

'National Collage of Business Administration \& Economics (NCBAE), Lahore, Pakistan

${ }^{2}$ National Collage of Business Administration \& Economics(NCBAE), Lahore, Pakistan

${ }^{3}$ National Collage of Business Administration \& Economics(NCBAE), Lahore, Pakistan

\begin{tabular}{|c|c|}
\hline KEYWORDS & BSTRACT \\
\hline $\begin{array}{l}\text { Light Triad Altruism, } \\
\text { Empathy, Compassion } \\
\text { Creative Self-Efficacy, } \\
\text { Psychological } \\
\text { Empowerment, } \\
\text { Self-Resilience \& } \\
\text { Innovative Performance }\end{array}$ & \multirow{3}{*}{ 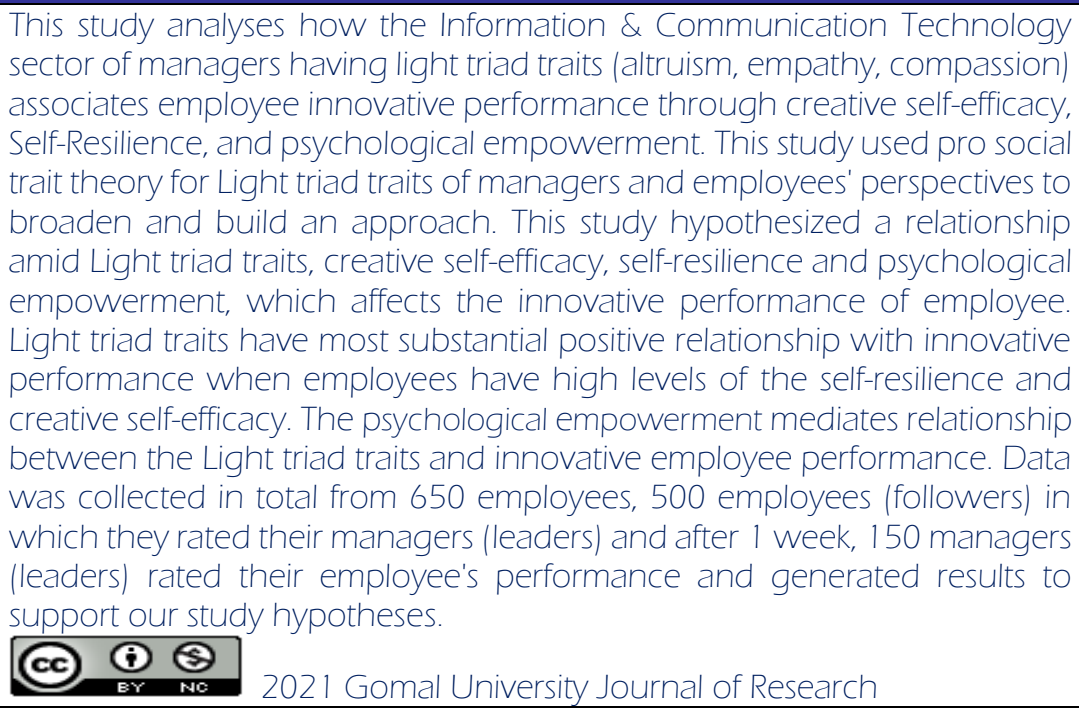 } \\
\hline Article History & \\
\hline & \\
\hline $\mathrm{CO}$ & ar: hod. \\
\hline $\mathrm{DOI}$ & \\
\hline
\end{tabular}

\section{INTRODUCTION}

In the globalized world, the developed countries are more focused on innovation capabilities to gain more and more to stay technological competition. Incorporate sectors, innovative potential has been studied more as researchers have seen more focus in developing countries to enhance their economies and creative potential to increase the investors, entrepreneurs and innovators, and developed countries capitalists. In global market competition, a continuous adaption of technological advancement in product structure is now focusing on their employee's roles to train their staff to build positive personality traits. This study focuses on the Light Triad Traits 
(altruism, empathy, and compassion), which is opposite side face or mirror reflection of Dark Triad personality traits (narcissism, Machiavellianism, and Psychopathy). The characteristics of LT are linked with prosocial traits, which are self-focused, emotional responding, empathetic concern (Staub, 2005; Safdar, Badir \& Afsar, 2017; Benedek, Bruckdorfer \& Jauk, 2020). The prosocial thoughts and feelings to help others who are in problems seek help from the higher management. Such prosocial behavior of leadership focuses on voluntarily help to build themself to feel other's issues as their own. In this connection, helping them with or without reward and feel spirituality high, confident at work level to perform more creatively with their team at the workplace.

The LT traits are "prosocial orientation" came under the umbrella of prosocial personality, the LT (altruism, empathy \& compassion) prosocial trait theory literature discussed but did not apply in the study, which is gap to study in the corporate sector of Pakistan. Leaders' light triad personality traits have not been checked in developed and developing countries; in this research, light triad traits (altruism, empathy, compassion) were studied as personality trait of managers (leaders) of firm. Light Triad (LT), one of positive traits of LT, Altruism (LTA), is a voluntary action in which the person's willingness to help others without thinking that action will cause effects in return. Even being generous with employees, manager did not know about rewards as feedback on their efforts. In LTA, altruistic personality trait of managers or leaders working in different firms helped their overworked colleagues, helping new employees in various tasks. Supporting employees who were absent without reason and LTA leaders help those employees who give up on their job if they experience problems. LT altruistic personality trait leaders always involve the employees who have issues to encountered (Guinot, Chiva \& Mallén, 2016). When employees are motivated by such prosocial behaviors, they feel inspired and work more energetic.

Employees feel relaxed due to the support of LT altruistic approach of the manager, improving productivity, working more creatively to generate the new ideas, and performing innovatively (Grant \& berry, 2011). Previous research shows that altruism may increase innovation process in the organization (Benedek et al., 2020). LTA helps employees to feel safe when they face problems and even in the case of making mistakes. It helps make good decisions, leading the organization towards innovation (Dierendonck \& Nuijten, 2011). Light Triad Empathy (LTE) personality trait of the managers, where they feel compassion, mindfulness for others, sadness, sympathy, grief, or suffering the LTE managers focus on their employee's emotions and feels their issues as their own (Batson, 2011). In simple words, LTE managers feel other emotions as their own or put their feet in another shoe. The managers provide such support to increase the employees' morale over LTE personality traits for organization benefit. Moral sympathy shows employees to work for organization's goals achievement on time with innovative performance. LTC managers suffer others' pain over mental state and behavioral actions show sympathetic consciousness and caring for workers who are in problems/stress over empathic communicative way (Dutton, Lilius \& Kanov, 2007). As. the "heart's response to others' suffering" (Kornfield, 2016).

Light Triad Empathy (LTE) is defined as "feeling in oneself feelings of others" (Egan, 2013). LTC managers improve employees' innovative performance suffering in service sectors (Rynes, Bartunek, Dutton \& Margolis, 2012). LTC absence in managers can lead organization workers towards stress, job dissatisfaction, and the high turnover rate, which caused loss to hire a new 
employee to train as per the organization terms and conditions. This behavior is very harmful to both employees and organization (Lilius, Worline, Maitlis, Kanov, Dutton \& Frost, 2008; Lipponen, Rajala \& Hilppö, 2018). LTC managers can reinforce connections between employees and the organization to increase more innovative performance to achieve a competitive edge. Psychological empowerment (PE) is concept of group cognitions and experience mental state. Definition of PE as 'process of heightening feelings of employee self-efficacy through identifying conditions that foster powerlessness and over their removal by formal organizational practices and informal techniques of providing efficacy information' (Conger \& Kanungo, 1988). In PE, the managers used empowerment to their employees to takes better decisions in the field of work as 'decentralization' concept, decisions moving from lower to upper staff, ensured that they have resources to perform innovative by making creative decisions. Managers are adept at increasing the moral support, confidence level, self-respect, motivational level, and giving help to perform innovatively and generate more organization outcomes (Javed, Khan, Bashir \& Arjoon, 2017).

Self-Resilience (SR) facilitates "positive adaptation in context of significant risk or adversity" (Ong, Bergeman, \& Boker, 2009, p. 1777). To avoid the effects of stress and increase the level of emotional strength. The broaden and build theory has been applied for SR (Fredrickson, 1998). In a stressful environment, high SR uses the protective shield in their behavior where they bounce back of the pressure they face in a workplace and find the positive meaning in a stressful situation (Tugade, Fredrickson \& Feldman, 2004). To tackle the environment where the force of stress bounces back to perform more innovatively at the work level (Javed et al., 2017). Innovative performance is defined as recognizing problems, initiation and planning to introduce novel ideas. Private information technology firms are large in number as compare to public firms. They have low resources with complex problems, and with limited time, they sort out these problems with innovative ideas. The information and communication firms need the innovation and solution to compete with others firms to gain market share (Safdar et al., 2017). In this connection, novel ideas about their products, services, and working method need to change in behavior, launch new ideas, and use the new way to increase the business level at the workplace place (individual, group, organization) (Jong \& Hartog, 2007). The LT traits, SR, PE, CSE, are positively associated with the IP of the employees working in the ICT sector of Pakistan.

\section{LITERATURE REVIEW}

The LTA managers are concerned with their employees by their helping behavior (Guinot et al., 2016). The prosocial behaviors of managers motivate their employees to work innovatively by improving productivity and go beyond their responsibilities to increase performance. To work in a different role and engage in creative work, they are inclined to create ideas and implement them to gain (helpful ideas) innovative performance (Grant \& Berry, 2011). LT altruistic behavior of managers may promote innovation within the organization (Escrig, Broch, Gómez \& Alcamí, 2016). A previous study found evidence of altruism and innovative behavior in public hospital research study (Vallina, Alegre \& Guerrero, 2018). LTE managers involve imagining what it is like for employees in the organization or sometimes called cognitive empathy or perspectivetaking. Sometimes it is called emotional empathy due to caring for their employees. Managers of LTE inspire their employees to avoid being harmless at work level. Empathy and creativity found in recent studies positive associations. The managers with prosocial behaviors intend toward charitable works or participating voluntarily to help others. The LTE managers, high the 
scores tend towards caring and want to help their employees. LTE managers can understand employees' emotions, and thus, such skills are helpful to make easier trust bonding with their staff.

Such LTE prosocial traits desire to develop strong bonding and cooperative relationships with employees. The recent studies have shown that LTC in the workplace correlates positively with organizational performance (Lilius et al., 2008). Since LTC is empathic response to suffering of others (Madden, Duchon, Madden \& Plowman, 2012). Previous research has shown that LTC employees in the workplace are more likely to generate positive emotions such as pride, gratitude, and inspiration, leading to deeper emotional engagement (Lilius et al., 2008). LTC also empowers employees to achieve a better work-life balance, thereby reducing interpersonal conflicts associated with the various critical organizational outcomes (Lilius, Worline, Dutton, Kanov \& Maitlis, 2011; Lipponen et al., 2018). In the previous research, job performance and compassion at works found positive service management (Lilius et al., 2008). Study suggested that social identity theory posits that interacting with others in social terms and LTC managers leads employees in innovative ways to perform without any stress and pain. The managers perceived their employees more favorable when their performance evaluated report (Dutton, Roberts \& Bednar, 2010). LTC managers encourage their employees to work more creatively, defining their problems, in results creative solutions for collective benefits, in case for employee emotional stability and innovative organization ideas generated and implemented to create an innovative performances (Dreu, Baas \& Nijstad, 2008; Baas, Roskes, Koch, Cheng \& Dreu, 2019).

In a globalized world, all firms need those creative employees who work very hard and perform innovatively (Ferreira, Coelho \& Moutinho, 2020). Employees participating in organizational activities with innovative and related to the innovation-related activities, in recent Creative Self-Efficacy (CSE), have essential role in defining individual differences related to innovation. Creative Self-Efficacy is Defined as a "self-view concept" (Tierney \& Farmer, 2002, p. 1,137). The social cognitive theory, CSE derived from this theory in which cognition, dynamic actions, and behavior of employees are influenced through the healthy environment (Gist \& Mitchell, 1992, p. 184). CSE by Tierney and Farmer (2002, p. 1,138) defines this construct as "the belief one can produce creative outcomes." This study also draws psychological empowerment as a mediator in literature (Maynard, Gilson \& Mathieu, 2012) to check independent and dependent variable relationship to generate more valuable results. Psychological empowerment increased the project outcomes at team level engagement (Malik et al., 2021), creating innovative results. To be empowered to successful projects generates very high incomes due to creative work. The perception of PE is to control the assigned work (Prati \& Zani, 2013). The PE of employees working in the organization has a perception of competence and can generate organizational outcomes.

Making great feelings in employees by empowering them leads organization to make strong bonding with their employees and make motivation and morale high because employees think they are an asset (Abbasi, Shabbir, Abbas \& Tahir, 2020). In reverse, they should know the organization's values. Therefore, the previous research concluded that the more employees working in a firm feel empowered, the more they know about their organization's values. The more workers know their organization, more they generate results in innovative performance because employees find their job very useful, meaningful and devote their job career very 
impactful. According to Cowen (1991), PE and SR are very important to promote their lower staff who are underserved and marginalized. The managers are concerned to support these communities to build psychology and practical advantages at the work level to encourage this community through SR and PE. The concept of PE is very profoundly rooted in community psychology, and on other hand, SR is readily observed in development psychology (Cattaneo \& Chapman, 2010). The concept of PE and SR is widely applied in the psychological community; 218 articles published from 1973 to 2012 were found in various studies. Wherein 81000 plus articles on PE related to science studies and 50000 reports are related to no-science, and thus conceptualization, critics, problem findings are researched in a different field of study. Thus, the community psychology journal therefore found six PE and SR articles (Finello \& Poulsen, 2012).

H1: Light Triad Altruism has a positive and significant relationship with innovative performance. H2: Light Triad Empathy has a positive and significant relationship with innovative performance. H3: Light triad compassion has a positive and significant relationship with innovative performance. H4: The Psychological empowerment has a positive relationship with the Light Triad Altruism. H5: The Psychological empowerment has a positive relationship with the Light Triad Empathy. H6: Psychological empowerment has a positive relationship with the Light Triad Compassion. H7: Innovative Performance has a positive relationship with the psychological empowerment. H8: Creative self-efficacy moderates relationship amid LTA and the innovative performance. H9: Creative Self-Efficacy moderates relationship between LTE and Innovative performance. H10: Creative Self-Efficacy moderates relationship between LTC and Innovative performance. H11: Self-Resilience moderates the relationship between PE and the Innovative performance.

\section{Figure 1}

Conceptual Model Method

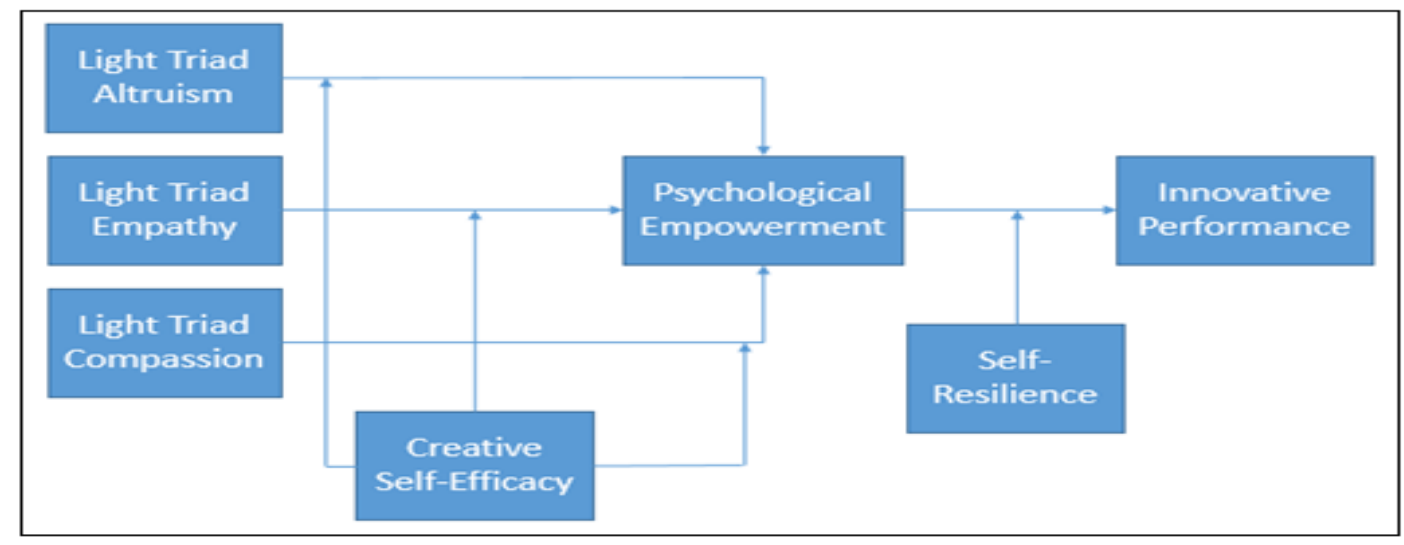

\section{RESEARCH METHODOLOGY}

All questionnaires are measured using a 5-point Likert scale, ranging from 1 strongly agree to 5 . The eight items of LTA (Items 3: "Doing volunteer work makes me feel happy"), eight items of LTE (Items 2: "When someone is feeling 'down' I can usually understand how they feel"), eight items of the LTC (Items 2: "My heart goes out to people who are unhappy"), the total 24 items of the Light Triad personality Traits used studies by Johnson (2018). The 13-item scale 
measuring innovative performance (Item 6: "Not afraid to take risks") used studies by Scott and Bruce (1994). A Self-Resilience 10-item scale adapted from the study of Campbell-Sills and Stein (2007). One of the SR items includes (Item 1: "I can adapt to change"). The 11 items of Psychological Empowerment (Item 3: "The work I do is meaningful to me") were taken from Zhang and Kathryn (2010). Three items of creative self-efficacy scale were taken from Tierney and Farmer (2002). Creative Self-efficacy sample item (Item 1: I have confidence in my ability to solve problems creatively). The variable details are shown in table 1 . According to Tanaka (1987), number of items is 610, and total 650 items surveyed were collected for further data analysis.

\section{Table 1}

Variables Details

\begin{tabular}{lllcl}
\hline Sr. & Items Variables Name & Author Name & Items & Tanaka \\
\hline 1 & Light Triad Personality Traits & Johnson, 2018 & 24 & 24 \\
2 & Innovative Performance & Scott \& Bruce, 1994 & 13 & $24+13=37$ \\
3 & Psychological Empowerment & Zhang et al., 2010 & 11 & $37+11=48$ \\
4 & Creative Self-Efficacy & Tierney \& Farmer, 2002 & 3 & $48+3=51$ \\
5 & Self-Resilience & Campbell-Sills and Stein (2007) & 10 & $51+10=61$ \\
\hline Total & & 58 & $61^{*} 10=610$ \\
\hline
\end{tabular}

\section{Correlation Analysis}

LTA, LTE, LTC, CSE, PE, and SR have a positive relationship with the DV that is IP which has been assumed, the values of correlation coefficient are $r=.791^{* *}, .501^{* *}, .565^{*}, .621^{* *}, .675^{* *}$, $.489^{* *} \mathrm{p}<0.01$ and $\mathrm{p}<0.05$. Therefore, the details of correlation analysis shown in table number 2.

\section{Table 2}

Correlation Analysis $(\mathrm{N}=650)$

\begin{tabular}{llrlllll}
\hline Sr. & Variables & 1 & 2 & 3 & 4 & 5 & 6 \\
\hline 1. & Light Triad Altruism (LTA) & & & & & & \\
2. & Light Triad Empathy (LTE) & $.598^{* *}$ & & & & & \\
3. & Light Triad Compassion (LTC) & $.671^{* *}$ & $.702^{* *}$ & & & & \\
4. & Creative Self-Efficacy (CSE) & $.698^{* *}$ & $.714^{* *}$ & $.649^{* *}$ & & & \\
5. & Psychological Empowerment (PE) & $.455^{* *}$ & $.679^{* *}$ & $.621^{* *}$ & $.589^{* *}$ & & \\
6. & Self-Resilience (SR) & $.572^{* *}$ & $.761^{* *}$ & $.731^{* *}$ & $.688^{* *}$ & $621^{* *}$ & \\
7. & Innovative Performance & $.791^{* *}$ & $.501^{* *}$ & $.565^{* *}$ & $.621^{* *}$ & $.675^{* *}$ & $.489^{* *}$ \\
\hline$*$ * Correlation is significant at the 0.01 level (2-tailed). & & & & \\
\hline
\end{tabular}

\section{CFA Measurement}

The measurement model of this study is developed to check the discriminant validity and to confirm the factor structures. To checking the associations among latent constructs, further which are measured the observed variables. To checking model figure number 1 , recommended values are X2/d.f. < 3, AGFI (adjusted goodness of fit index) > 0.80, GFI (goodness of fit index) $>0.9$; > 0.8, RMSEA (root mean square error of approximation) < 0.039, RMR (root mean square residual) <0.09, PCLOSE $>0.05$ and CFI (comparative fit index) > 0.95; > 0.09; >0.08. 
in this connection, values of the current study measurement model are X2/d.f. 2.003, AGFI .847, GFI .847, RMSEA .043, RMR .088, PCLOSE 1.0 and CFI 857 (Gronemus et al., 2010).

\section{Figure 2}

CFA Measurement model

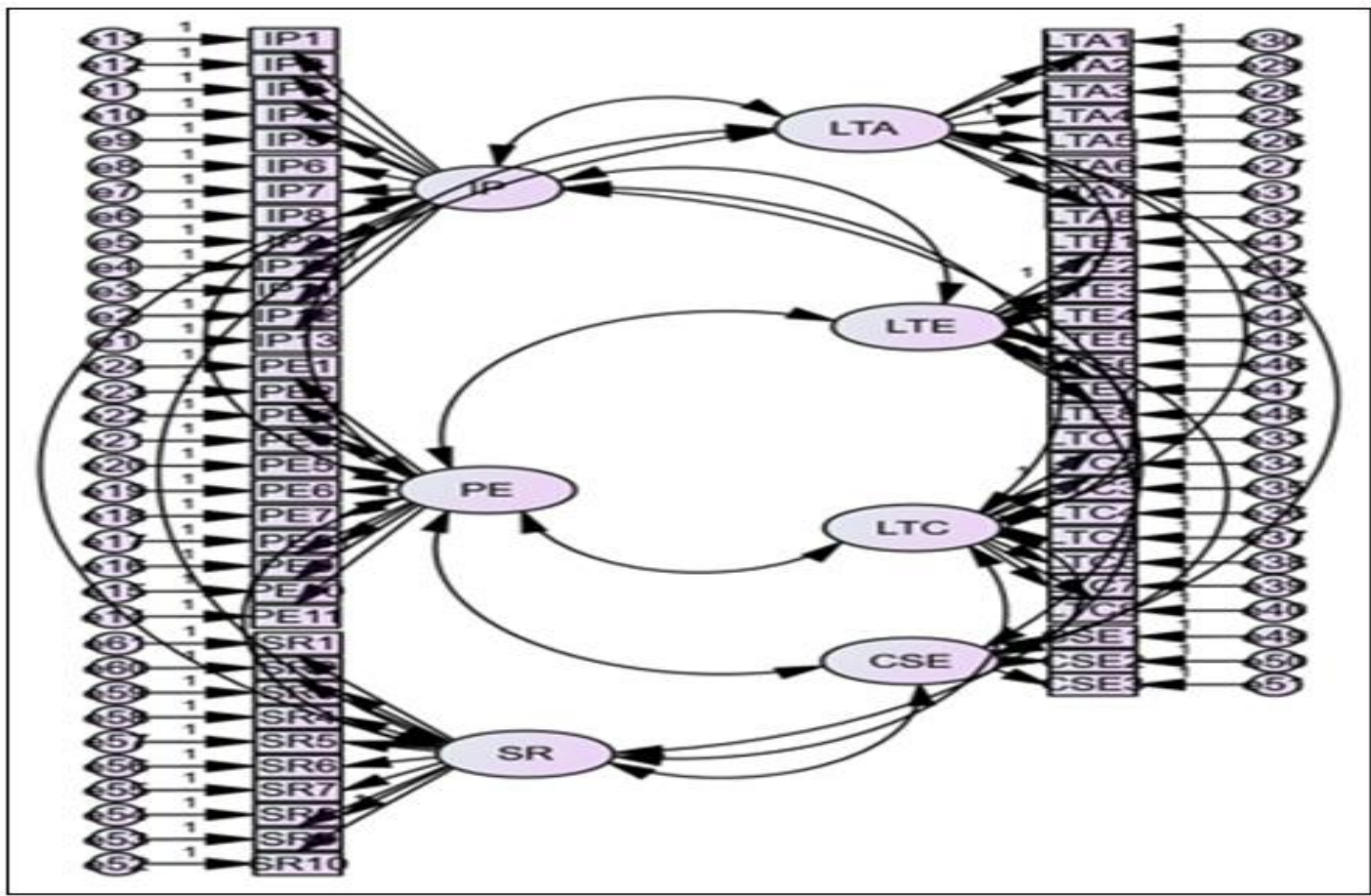

\section{RESULTS OF STUDY}

The results show in Table 2 that there is a direct positive significant relationship between LTA and IP; LTE and IP, LTC and IP, LTA and PE, LTE and PE, LTC and PE; PE and IP.

Table 3

Regression Weights: (Group number 1-Default model)

\begin{tabular}{lllcccccc}
\hline & & & Estimate & SE & CR. & P & \multicolumn{2}{c}{ Hypothesis } \\
\hline LTA & $\leftarrow$ & IP & .402 & .039 & 11.889 & $* * *$ & H1 & Accepted \\
LTE & $\leftarrow$ & IP & .515 & .037 & 12.589 & $* * *$ & H2 & Accepted \\
LTC & $\leftarrow$ & IP & .607 & .041 & 24.897 & $* * *$ & H3 & Accepted \\
PE & $\leftarrow$ & LTA & .609 & .043 & 19.567 & $* * *$ & H4 & Accepted \\
PE & $\leftarrow$ & LTE & .612 & .031 & 26.121 & $* * *$ & H5 & Accepted \\
PE & $\leftarrow$ & LTC & .589 & .029 & 12.899 & $* * *$ & H6 & Accepted \\
\hline PE & $\leftarrow$ & IP & .512 & .034 & 17.221 & $* * *$ & H7 & Accepted \\
\hline
\end{tabular}

Path-LT (LTA, LTE, LTC)-PE-IP 
PE performs as a mediator between LT (LTA, LTE, LTC) independent variables and IP as dependent variable. To checked the direct beta without mediator between independent variables and dependent variable values are $\beta=.598, .458, .681$ and level of significance values are $\mathrm{p}=.009, .007, .005$. after that we calculate the next step to checked the direct beta value with the presence of mediator value, the values are $\beta=.369, .468, .465$ and level of significance values are $\mathrm{p}=.008, .010, .012$. the final step is to calculate the indiect beta values which are $\beta$ $=.388, .521, .691$ and the level of significance values are $p=.011, .013, .006$.

\section{Table 4}

\section{Inference for Mediation}

\begin{tabular}{|l|c|c|c|c|}
\hline Hypothesis & $\begin{array}{c}\text { Direct Beta without } \\
\text { Mediator }\end{array}$ & $\begin{array}{c}\text { Direct Beta with } \\
\text { Mediator }\end{array}$ & Indirect Beta & $\begin{array}{c}\text { Mediation type } \\
\text { observed }\end{array}$ \\
\hline LTA-PE-IP & Beta $=.598$ & $\mathrm{~B}=.369$ & $\mathrm{~B}=.388$ & Partial \\
& $\mathrm{P}=.009$ & $\mathrm{P}=.008$ & $\mathrm{P}=.011$ & Mediation \\
\hline LTE-PE-IP & Beta $=.458$ & $\mathrm{~B}=.468$ & $\mathrm{~B}=.521$ & Partial \\
& $\mathrm{P}=.007$ & $\mathrm{P}=.010$ & $\mathrm{P}=.013$ & Mediation \\
\hline LTC-PE-IP & $\mathrm{Beta}=.681$ & $\mathrm{~B}=.465$ & $\mathrm{~B}=.691$ & Partial \\
& $\mathrm{P}=.005$ & $\mathrm{P}=.012$ & $\mathrm{P}=.006$ & Mediation \\
\hline
\end{tabular}

\section{Figure 3}

Path-LTA-PE-IP
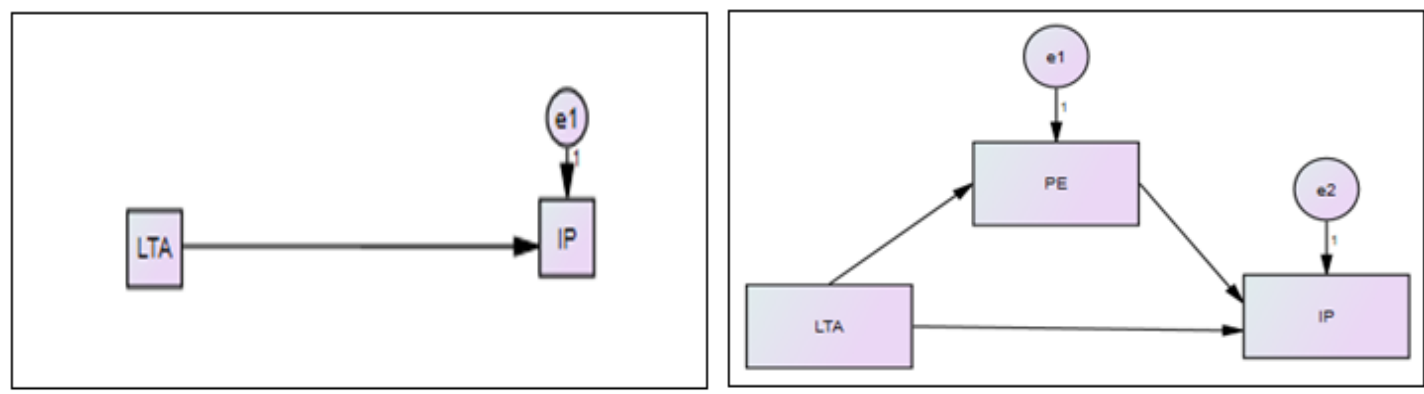

Figure 4

Path-LTE-PE-IP
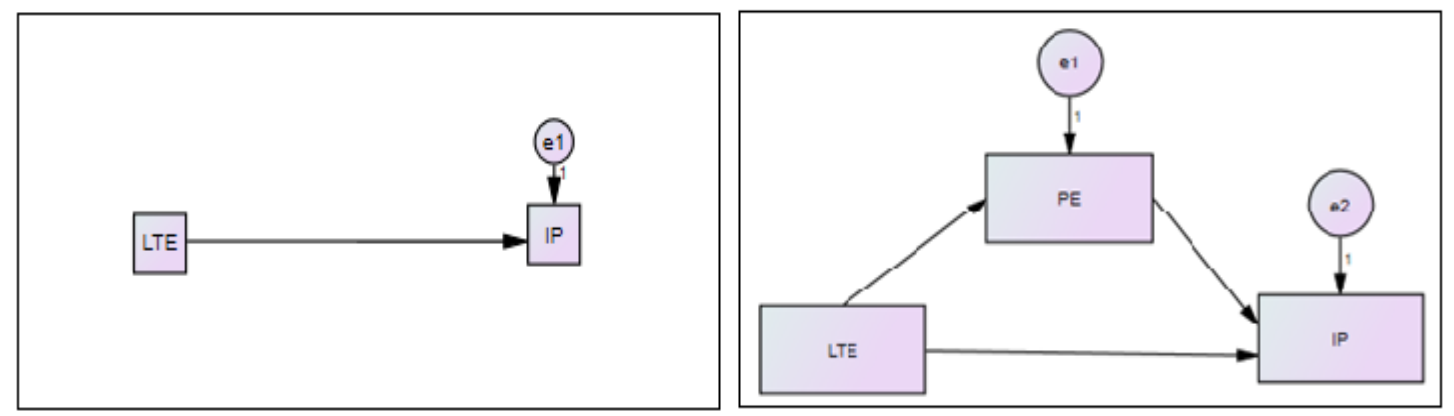


\section{Figure 5}

Path-LTC-PE-IP
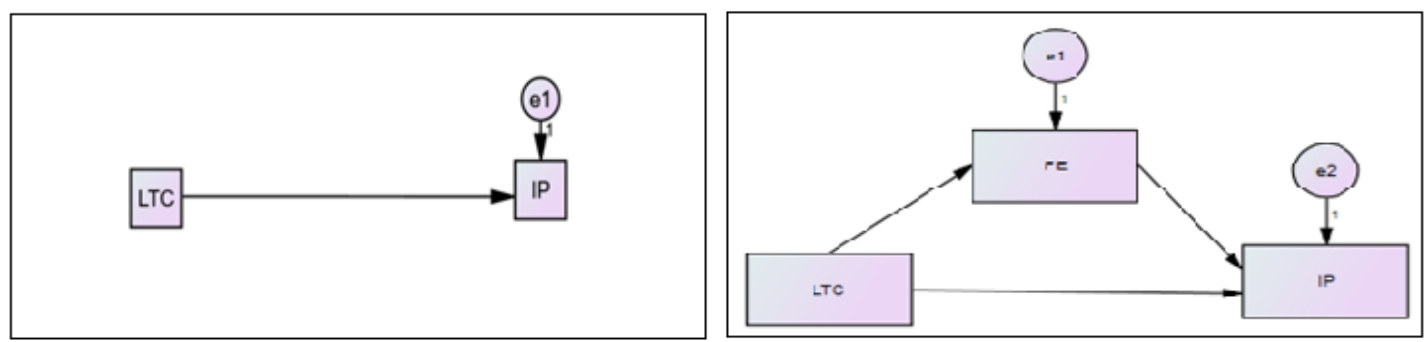

The conclusion of mediation of all values that checked with the mediator and without mediator effect of a direct and indirect impact. The values showed that indirect effect through the PE as mediator values are significant between LTA-IP, LTE-IP, LTA-IP. So the results of mediation shown partial mediation effect of PE with LTA-IP, LTE-IP, LTA-IP, and hypotheses are partially supported.

\section{CSE moderates between LTA and IP.}

The moderation graph results generated through StatTool software, Creative Self-Efficacy (CSE), play a Moderator role between LTA and IP. The B value unstandardized regression coefficients of all variables get through the linear regression in SPSS. The independent variable LTA whose $B$ values unstandardized regression coefficients is $B 1=.761(\mathrm{p}<.001)$. in this connection, the moderator value of the unstandardized regression coefficients is $\mathrm{B} 2=.678(\mathrm{p}<.001)$. The unstandardized regression coefficient value of interaction LTA and CSE is B $=.251$ ( $\mathrm{p}<.001)$. Thus, the positive and significant relationship between LTA and IP is shown in figure number 5 .

\section{Figure 6}

CSE strengthens the positive relationship between LTA and IP.

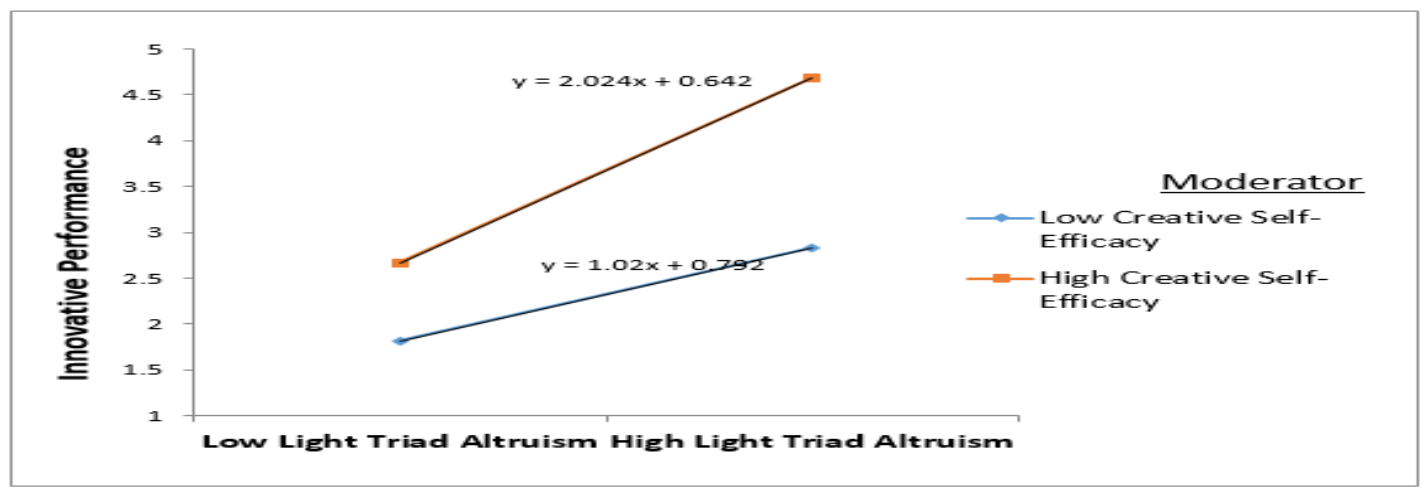

\section{CSE moderates between LTE and IP.}

The moderation graph results generated through the StatTool software, Creative Self-Efficacy (CSE), play a Moderator role between LTE and IP. The B value unstandardized regression coefficients of all variables get through the linear regression in SPSS. The independent variable 
LTE whose $B$ values unstandardized regression coefficients is $\mathrm{B} 1=.679(\mathrm{p}<.001)$. The moderator value of unstandardized regression coefficients is $\mathrm{B} 2=.678(\mathrm{p}<.001)$. The unstandardized regression coefficient value of interaction LTE and CSE is B $=.198(\mathrm{p}<.001)$. The positive and significant relationship between LTE and IP is shown in figure number 6 .

\section{Figure 7}

CSE strengthens the positive relationship between LTE and IP.

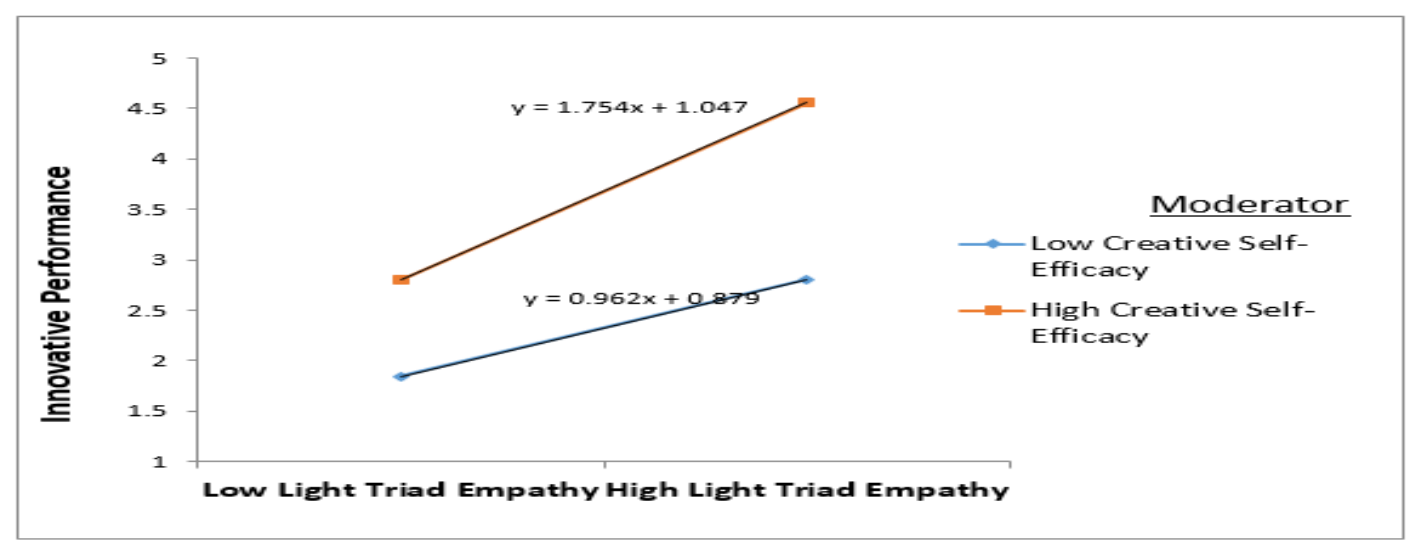

\section{CSE moderates between LTC and IP.}

The moderation graph results generated through the StatTool software, Creative Self-Efficacy (CSE), play a Moderator role between LTC and IP. The B value unstandardized regression coefficients of all variables get through the linear regression in SPSS. The independent variable LTC whose $B$ values unstandardized regression coefficients is $\mathrm{B} 1=.701(\mathrm{p}<.001)$. Moderator value of unstandardized regression coefficients is $\mathrm{B} 2=.678(\mathrm{p}<.001)$. In this connection, the unstandardized regression coefficient value of interaction LTC and CSE is B $=.261(p<.001)$. Thus, the positive and significant relationship between LTC and IP is shown in figure number 7.

\section{Figure 8}

CSE strengthens the positive relationship between LTC and IP.

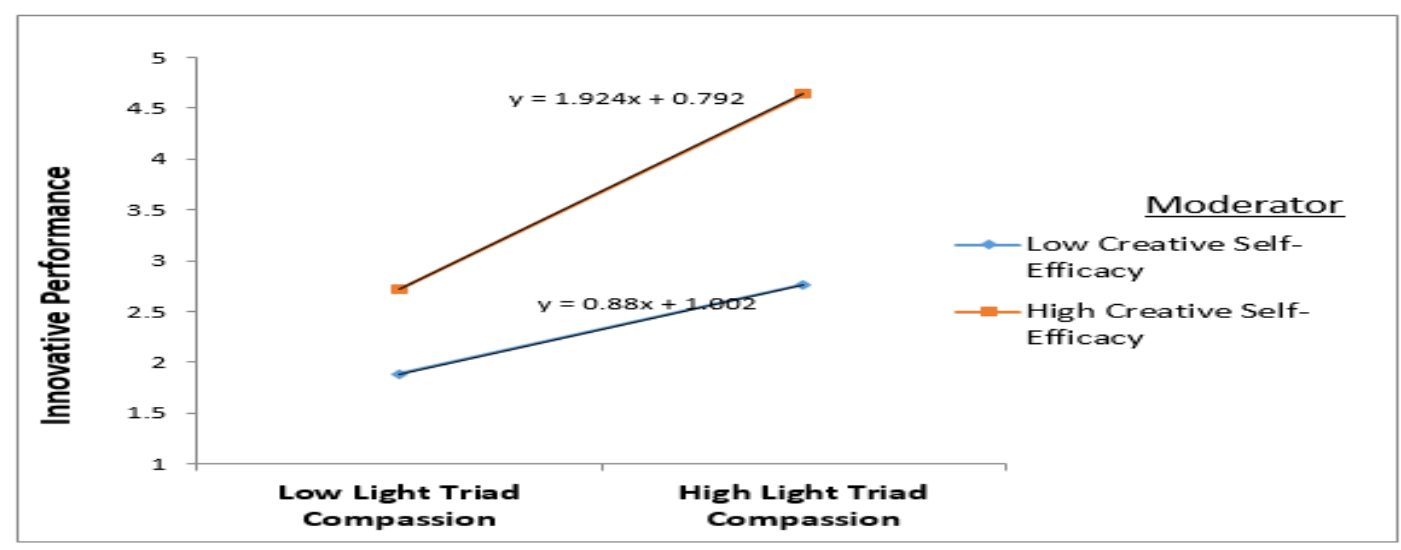




\section{SR moderation between PE and IP.}

The moderation graph results generated through the StatTool software, Self-Resilience (SR), play the Moderator role between the Psychological Empowerment (PE) and IP. The B value of unstandardized regression coefficients of all the variables get through the linear regression in SPSS. The independent variable PE whose $\mathrm{B}$ values unstandardized regression coefficients is $\mathrm{B} 1=.621(\mathrm{p}<.001)$. The moderator value of the unstandardized regression coefficients is $\mathrm{B} 2=$ $.602(\mathrm{p}<.001)$. The unstandardized regression coefficient value of interaction $\mathrm{PE}$ and $\mathrm{SR}$ is $\mathrm{B}=$ $.211(\mathrm{p}<$.001). Positive and significant relationship between PE and IP is shown in figure number 8.

\section{Figure 9}

Self-Resilience strengthens positive link amid Psychological Empowerment and Innovative Performance.

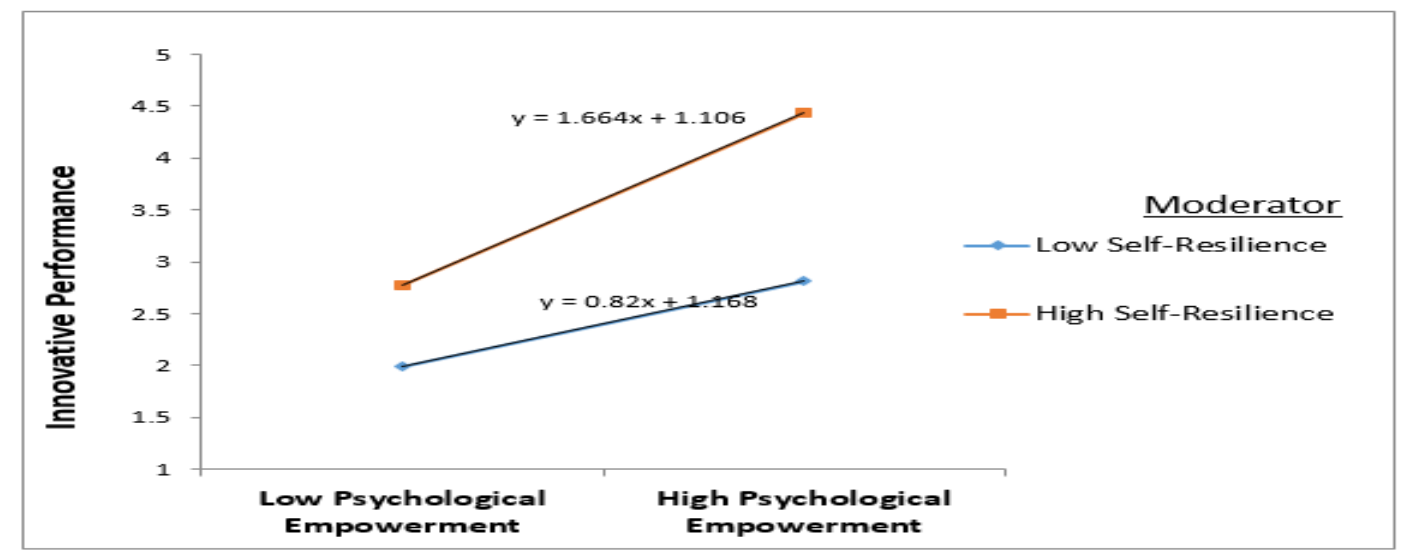

\section{DISCUSSION AND CONCLUSION}

This study invested the Light Triad (LTA, LTE, LTC), SR, PE, CSE, and IP interaction complex model in prosocial theory. This model shows that the LT traits of managers can improve their employee's IP. The CSE can be mediated to enhance the performance and shows positive and significant results. In this research, researcher first built a conceptual model to test importance of LT traits to improve the IP of employees (Hallak, Assaker, O'Connor \& Lee, 2018). So CSE can increase the IP of employees if managers have LT traits. In this regard, SR also strengthens positive relationship between PE and IP. Light Triad traits make strong building with their employees due to intense caring, compassion, altruism, empathy, which are positive affections or waves with employees (Santoro, Messeni \& Giudice, 2021). To help managers to increase innovative performance through employees because employees are assets of the company (Liu, Gong, Zhou \& Huang, 2017). In this connection, the supportive encouragement and inspiration will grow the IP and LT traits and decrease the anxiety, tension, and fear in employees' lives, making managers increase IP at the work level by creating a solid bonding with organization employees.

\section{Limitations \& Future Research}

The study measured through subjective scores, in which managers rate their employees and employees rate their managers, biased of usual sources avoided. The objective survey increases 
our confidence level when copying the results because the LTA, LTE, LTC, PE, SR. addresses the individual's internal structure. Secondly, future researchers can collect the data from other businesses. Additional tests are needed to test this model in different world regions because this study was conducted in Pakistan. The results gathered from the ICT firms differ from those of other countries. Future research should focus on ambidextrous leadership, transformational leadership, performance measurement, reward systems, other personality traits. Future research also improves proposed model by adding additional variables to improving and explaining the IP.

\section{REFERENCES}

Abbasi, S. G., Shabbir, M. S., Abbas, M., \& Tahir, M. S. (2020). HPWS and knowledge sharing behavior: The role of psychological empowerment and organizational identification in public sector banks. Journal of Public Affairs, e2512.

Baas, M., Roskes, M., Koch, S., Cheng, Y., \& De Dreu, C. K. (2019). Why social threat motivates malevolent creativity. Personality and Social Psychology Bulletin, 45(11), 1590-1602.

Batson, C. D. (2011). Altruism in humans. Oxford university press, USA.

Benedek, M., Bruckdorfer, R., \& Jauk, E. (2020). Motives for creativity: Exploring the what and why of everyday creativity. The Journal of Creative Behavior, 54 (3), 610-625.

Campbell-Sills, 1., \& Stein, M. B. (2007). Psychometric analysis and refinement of the connordavidson resilience scale (cd-risc): validation of a 10-item measure of resilience. Journal of traumatic stress: Official publication of international society for traumatic stress studies, 20(6), 1019-1028.

Cattaneo, L. B., \& Chapman, A. R. (2010). The process of empowerment: A model for use in research and practice. American psychologist, 65(7), 646.

Conger, J. A., \& Kanungo, R. N. (1988). The empowerment process: Integrating theory and practice. Academy of Management Review, 13(3), 471-482.

Cowen, E. L. (1991). In pursuit of wellness. American psychologist, 46(4), 404.

Crowder, R. (2016). Mindfulness based feminist therapy: The intermingling edges of self-compassion and social justice. Journal of religion \& spirituality in social work: social thought, 35(1-2), 24-40.

Dierendonck, D., \& Nuijten, I. (2011). The servant leadership survey: Development and validation of a multidimensional measure. Journal of business and psychology, 26(3), 249-267.

Dreu, C. K., Baas, M., \& Nijstad, B. A. (2008). Hedonic tone and activation level in the mood-creativity link: toward a dual pathway to creativity model. Journal of personality and social psychology, 94(5), 739.

Dutton, J. E., Lilius, J. M., \& Kanov, J. M. (2007). The transformative potential of compassion at work. Handbook of transformative cooperation: New designs and dynamics, 1 , 107-126.

Dutton, J. E., Roberts, l. M., \& Bednar, J. (2010). Pathways for positive identity construction at work: four types of positive identity and the building of social resources. Academy of management review, 35(2), 265-293.

Egan, G. (2013). The skilled helper: A problem-management and opportunity-development approach to helping. Cengage learning. 
Escrig, E. D., Broch, F. F. M., Gómez, R. C., \& Alcamí, R. L. (2016). How does altruistic leader behavior foster radical innovation? The mediating effect of organizational learning capability. Leadership \& organization development journal.

Ferreira, J., Coelho, A., \& Moutinho, l. (2020). Dynamic capabilities, creativity and innovation capability and their impact on competitive advantage and firm performance: Moderating role of entrepreneurial orientation. Technovation, 92, 102061.

Finello, K. M., \& Poulsen, M. K. (2012). Unique system of care issues and challenges in serving children under age 3 and their families. American journal of community psychology, 49(3-4), 417-429.

Fredrickson, B. L. (1998). Cultivated emotions: parental socialization of positive emotions and self-conscious emotions. Psychological inquiry, 9(4), 279-281.

Gist, M. E., \& Mitchell, T. R. (1992). Self-efficacy: a theoretical analysis of its determinants and malleability. Academy of management review, 17(2), 183-211.

Grant, A. M. (2008). Does intrinsic motivation fuel the prosocial fire? Motivational synergy in predicting persistence performance and productivity. Journal of applied psychology, 93(1), 48.

Grant, A. M., \& Berry, J. W. (2011). The necessity of others is the mother of invention: intrinsic and prosocial motivations, perspective taking, and creativity. Academy of management journal, 54(1), 73-96.

Gronemus, J. Q., Hair, P. S., Crawford, K. B., Nyalwidhe, J. O., Cunnion, K. M., \& Krishna, N. K. (2010). Potent inhibition of the classical pathway of complement by a novel c1q-binding peptide derived from human astrovirus coat protein. Molecular immunology, 48(1-3), 305-313.

Guinot, J., Chiva, R., \& Mallén, F. (2016). Linking altruism and organizational learning capability: A study from excellent human resources management organizations in Spain. Journal of business ethics, 138(2), 349-364.

Hallak, R., Assaker, G., O'Connor, P., \& Lee, C. (2018). Firm performance in the upscale restaurant sector: The effects of resilience, creative self-efficacy, innovation and industry experience. Journal of Retailing and Consumer Services, 40, 229-240.

Javed, B., Khan, A. A., Bashir, S., \& Arjoon, S. (2017). Impact of ethical leadership on creativity: the role of psychological empowerment. Current issues in tourism, 20(8), 839-851.

Johnson, L. K. (2018). The light triad scale: developing and validating a preliminary measure of prosocial orientation.

Jong, J. P., \& Hartog, D. N. (2007). How leaders influence employees' innovative behaviour. European journal of innovation.

Kornfield, J. (1993). A path with heart: a guide through the perils and promises of spiritual life. New York, NY: bantam.

Lilius, J. M., Worline, M. C., Dutton, J. E., Kanov, J. M., \& Maitlis, S. (2011). Understanding compassion capability. Human relations, 64(7), 873-899.

Lilius, J. M., Worline, M. C., Maitlis, S., Kanov, J., Dutton, J. E., \& Frost, P. (2008). The contours and consequences of compassion at work. Journal of organizational behavior, 29(2), 193-218.

Lipponen, L., Rajala, A., \& Hilppö, J. (2018). Compassion and emotional worlds in early childhood education. Early childhood education and change in diverse cultural contexts.

Liu, D., Gong, Y., Zhou, J., \& Huang, J. C. (2017). Human resource systems, employee creativity, and firm innovation: The moderating role of firm ownership. Academy of management journal, 6o(3), 1164-1188. Doi:10.5465/amj.2015.0230 
Madden, l. T., Duchon, D., Madden, T. M., \& Plowman, D. A. (2012). Emergent organisational capacity for compassion. Academy of management review, 37(4), 689-708.

Malik, M., Sarwar, S., \& Orr, S. (2021). Agile practices and performance: examining the role of psychological empowerment. International journal of project management,39(1), 10-20.

Maynard, M. T., Gilson, L. L., \& Mathieu, J. E. (2012). Empowerment-fad or fab? A multilevel review of the past two decades of research. Journal of management, 38(4), 1231-1281.

Ong, A. D., Bergeman, C. S., \& Boker, S. M. (2009). Resilience comes of age: defining features in later adulthood. Journal of personality, 77(6), 1777-1804.

Prati, G., \& Zani, B. (2013). The relationship between psychological empowerment and organisational identification. Journal of community psychology, 41(7), 851-866.

Rynes, S. L., Bartunek, J. M., Dutton, J. E., \& Margolis, J. D. (2012). Care and compassion through an organizational lens: Opening up new possibilities.

Safdar, U., Badir, Y. F., \& Afsar, B. (2017). Who can I ask? How psychological safety affects knowledge sourcing among new product development team members. The Journal of High Technology Management Research, 28(1), 79-92.

Santoro, G., Messeni, A., \& Del Giudice, M. (2021). Searching for resilience: The impact of employee-level and entrepreneur-level resilience on firm performance in small family firms. Small Business Economics, 57(1), 455-471.

Scott, S. G., \& Bruce, R. A. (1994). Determinants of innovative behavior: a path model of individual innovation in the workplace. Academy of management journal,37(3), $580-607$.

Staub, E. (2005). The roots of goodness: Fulfillment of basic human needs and the development of caring, helping and nonaggression, inclusive caring, moral courage, active bystandership, and altruism born of suffering.

Tanaka, J. S. (1987). " How big is big enough?": sample size and goodness of fit in structural equation models with latent variables. Child development, 134-146.

Tierney, P., \& Farmer, S. M. (2002). Creative self-efficacy: its potential antecedents and relationship to creative performance.Academy of management journal,45(6), 1137-1148.

Tugade, M. M., Fredrickson, B. L., \& Feldman, B. l. (2004). Psychological resilience and positive emotional granularity: examining the benefits of positive emotions on coping and health. Journal of personality, 72(6), 1161-1190.

Vallina, A., Alegre, J., \& Guerrero, R. F. (2018). Happiness at work in knowledge-intensive contexts: opening the research agenda. European research on management and business economics, 24(3), 149-159.

Zhang, X., \& Kathryn, M. (2010). "Linking empowering leadership and employee creativity: The influence of psychological empowerment, intrinsic motivation and creative process engagement. Academy of management journal, 53, 107-128. 